\title{
Drinking Water Disinfection by Solar Radiation
}

\author{
Arzu Teksoy*, Sevil Çalışkan Eleren \\ Faculty of Engineering, Uludag University, Turkey
}

Copyright $\subset 2017$ by authors, all rights reserved. Authors agree that this article remains permanently open access under the terms of the Creative Commons Attribution License 4.0 International License

\begin{abstract}
A primary concern of developing countries throughout the world is that of obtaining safe drinking water. Waterborne diseases are still common in developing countries since drinking water sources are contaminated and the conventional rural water treatment plants are often inefficient to produce safe drinking water. This situation in developing countries is a major problem in terms of preventing public health. It is estimated that diarrhea accounted for $99 \%$ of the 69 million deaths among children before the age of five. Inadequate operation and maintenance after installations caused by a lack of trained operators, by a treacherous supply of chemicals and spare parts, and by financial problems lead to produce unhealthy drinking water. Since major urban water supplies are also not always capable of maintaining a regular supply of qualitatively good water, the distributed water is often considered unsafe for direct consumption. Treatment of water at the household level (etc. boiling) or purchasing of mineral water for consumption is more real than an exception in urban areas of developing countries. Recently, another small-scale approach using the lethal effect of sunlight has gained importance to sanitary contaminated water. Solar disinfection (SODIS) is one of the simplest methods for providing acceptable quality drinking water and consists of filling transparent containers (plastic bags, plastic bottles or glass bottles) with water and exposing the containers to sunlight for approximately 6 hours. Because of the low cost and easy usage, solar disinfection is commonly used in developing countries in Asia, Africa and South America. The aim of this literature review is to give information about solar disinfection mechanism, to compare the efficiency of solar disinfection on different microorganisms based on the past studies, and to discuss the several applications of solar disinfection in the world.
\end{abstract}

Keywords Drinking Water, Microorganism, Rural Area, Solar Disinfection

\section{Introduction}

Supplying safe drinking water is one of the most important issues in terms of sustainability of life. However, water resources are increasingly threatened with increasing population density, overuse and wastage [1]. According to the World Health Organization (WHO), 884 million people lack from the access to improved water supplies. In the context of the envisaged energy crisis in the future, problems with the provision of healthy drinking water are expected to worsen, or it is expected that the water problems will increase the energy problems due to the close relation between water and energy [2]. In this case, it is important to ensure that drinking water is supplied in sufficient quantity and quality, continuously and economically for developing countries $[3,4]$.

There is a significant amount of microbial pathogens in sewage systems. Viruses as well as bacteria and many protozoans occur in the sewage system. Although many pathogens can be removed by treatment systems, most of them are discharged in the effluent and reached to surface waters [5]. Wastewater and contaminated water used for irrigating, drinking, and recreational purposes have been widely related to the transmission of infectious viral diseases among human populations [6-9].

Waterborne diseases are still common as water resources are contaminated with pathogens; and conventional rural treatment processes are often inadequate to produce safe drinking water in developing countries. The inadequacy of water resources forces microbiologically unsafe water usage which causes the transmission of epidemics including cholera, typhoid, hepatitis $[1,10,11]$. In developing countries, $50 \%$ of the population is exposed to polluted water resources, resulting in 4 billion diarrhea cases each year due to inadequate supplies of water for personal care and insufficient treatment. Therefore, 2.2 million people, the majority of whom are under the age of 5 , lose their lives every year $[1,11]$.

Although the interventions in the distribution network have been shown to reduce diarrhea, current research has demonstrated that point of use applications within the household can be more effective. However, these applications must have certain criteria such as low cost, easy use and sustainability. In addition to boiling, chlorination and filtration, sunlight disinfection has gained popularity as a household water disinfection method in recent years [10].

Solar disinfection (SODIS) is an efficient, low technology 
and cost-effective method for inactivation of pathogenic microorganisms in low-income communities where clean drinking water providing is limited or absent. [12]. The use of sunlight for supplying healthy water is not a new phenomenon. It has been demonstrated that solar disinfection inactivates microorganism by direct exposure is volume independent economic process and avoids production of hazardous by-products of chemically driven technologies [13].

Solar radiation removes a broad range of microorganisms such as viruses, bacteria and protozoa [14]. Contaminated drinking water in the transparent carriers such as plastic bottles, bags and glass bottles are placed in direct sunlight for at least 6 hours prior to consumption [14-16]. Destruction of microorganisms during solar disinfection is achieved by the synergistic effects of mild heat and UV radiation, leading to pasteurization and UV disinfection [17]. In addition, pathogens are removed by indirectly with the photosensitizer which absorbed UV light and produced reactive oxygen species by reacting with oxygen in water [18].

The efficacy of solar disinfection is affected by several factors including presence of organic and inorganic compounds and dissolved oxygen in water, solar light intensity, temperature, type of container and nature of microorganisms $[1,19]$.

Since it is very important to provide healthy drinking water economically in developing countries, the household water treatment method is a matter to be considered. Several modifications such as thermal enhancement, heterogeneous photocatalysis, chemical addition, flow reactors, solar mirrors have been developed to enhance the effectiveness of solar disinfection on pathogens especially viruses and protozoa which are very resistant to disinfection because of several limitations of traditional solar disinfection [20]. These systems are crucial in reducing the incidence of gastrointestinal infection in communities where supplying clean drinking water is limited or absent.

The aim of this literature review is to give information about solar disinfection mechanism, to compare the efficiency of solar disinfection on different microorganisms based on the previous studies, and to discuss the several applications of solar disinfection on the worldwide [21-23].

\section{Fundamental Aspects of Solar Disinfection}

Solar disinfection is affected by several variables such as solar radiation wavelengths, water temperature, turbidity, and container type [1].

\subsection{Solar Radiation Wavelengths}

The inactivation effect of sunlight on microorganisms has been known for 4000 years [16]. The spectrum of solar energy that reaches the Earth's surface is very broad covering radiation wavelengths of generally $300 \mathrm{~nm}$ and upwards $[15,24,25]$. Studies have shown that the components of sunlight such as UV-A (wavelengths, 320 to $400 \mathrm{~nm}$ ), UV-B, and UV-C radiation are able to inactivate microorganisms [26-27]. UV-C radiation has the greatest efficiency on inactivation because of its absorption by DNA. UV-C (at $254 \mathrm{~nm}$ ) leads to changes in nucleic acids and other structures such as enzymes and immunogenic antigens of microorganisms. However, UV-C component of solar radiation does not reach the earth [15]. Since wavelengths below $290 \mathrm{~nm}$ do not reach the earth, it has been concluded that the most bactericidal wavelengths are between 315 to $400 \mathrm{~nm}[15,17,24,25,28,29]$

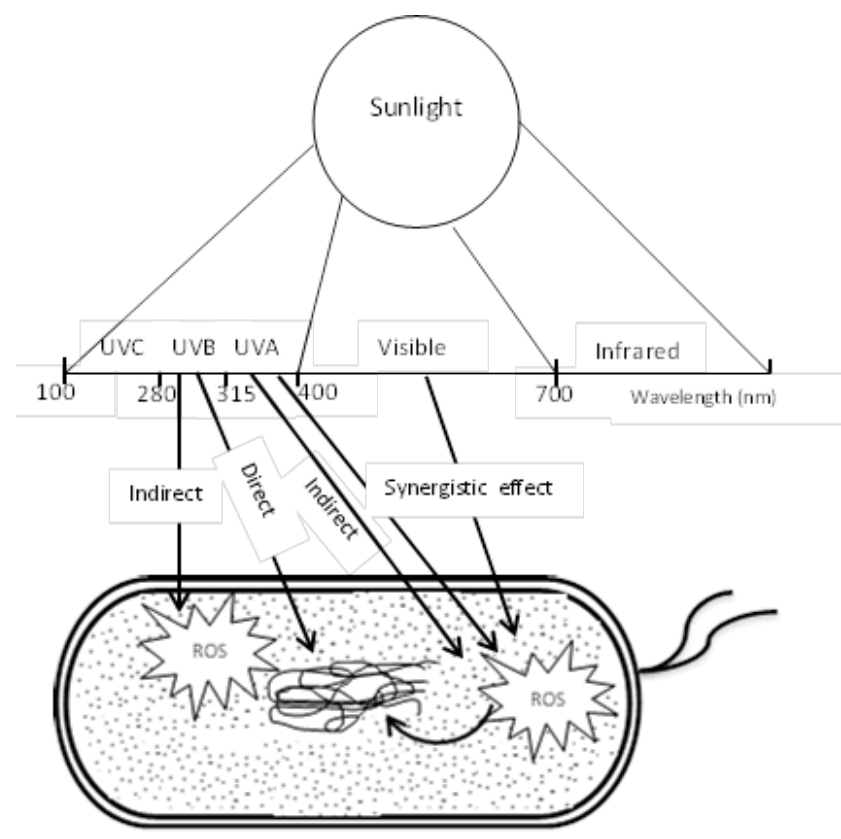

Figure 1. Effects of solar light on microorganisms (Adapted by Silverman et al. [30])

UV-B light (290-320 nm) affects considerably organisms in water since its germicidal effect is $100-1000$ times more efficient than UV- A. It damages cellular components (chromophores, enzymes, vitamins), genetic materials and proteins of organism, while UV-A leads oxidation of pyrimidines, purines and CPD (Cyclo butane pyrimidine dimers), strand breaks [31]. Synergistic effects of UV-A and violet light are responsible for inactivation of microorganisms by UV-A light $(320-400 \mathrm{~nm})$ which is principle wavelight region. Besides other cell damage, reactive oxygen species (ROS) can lead to lipid peroxidation, pyrimidine dimer formation and even DNA lesions. When ROS interacts with DNA, single strand breaks occur as well as nucleic base modifications which may be lethal and mutagenic for microorganisms. Apart from DNA; UV-A light affects compounds which are vital for a metabolic cycle and cell homeostasis. The irradiation of intracellular chromophores with UV-A light in the presence of oxygen results absorption through chromophores contributes the generation of ROS [32]. 


\subsection{Heating}

Heating is accomplished by sunlight during solar exposure [28, 33, 34]. Previous researches showed that most of the microorganisms are inactivated when they exposed to temperatures of over about $70^{\circ} \mathrm{C}$ for a certain period of time. Water temperatures within the bottles heated with solar energy in a solar hot box are raised to $65^{\circ} \mathrm{C}$ or higher degrees $[23,35]$. Thus, the synergistic effect of optical and thermal inactivation processes leads higher reductions of E.coli, Salmonella enterica serotypes typhi, paratyphi and enteritidis, Shigella flexneri, Pseudomonas aeruginosa, Enterococcus faecalis and Vibrio cholerae. Thermal inactivation has not been reported for water temperatures $<$ $40^{\circ} \mathrm{C}$. Fecal indicators are inactivated in heated water up to $62^{\circ} \mathrm{C}$ and above, while spore-forming bacteria are never completely inactivated at these temperatures [36]. E. coli can be reduced by $3 \operatorname{logs}$ with pasteurization at $65^{\circ} \mathrm{C}$ within 3 hours. The same reductions can be achieved in a combination of solar disinfection and pasteurization within 2 hours at $56^{\circ} \mathrm{C}[37]$.

Resistant organisms such as protozoal oocyst cannot be inactivated by heating during sunlight exposure; however, their infection potential can be reduced effectively. Infectivity studies on oocysts showed that Cryptosporidium parvum oocyst in turbid water exposed for 4,8 and 12 hours to solar light caused significant decrease in the intensity of infection on mice at the end of all exposure times depending on thermal inactivation [38].

\subsection{Impurities}

Turbidity is a significant factor in the solar disinfection since hinder of light to transmit through water. It has been concluded that higher turbidity samples exposed to sunlight had less inactivation of E. coli compared to samples with little or no turbidity. This may be occurred due to the protective effect of particulate matter [22, 23, 39]. Suspended solids need to be reduced to a maximum of $5 \mu \mathrm{m}$ in order to achieve effective inactivation. Sunlight has no lethal effect on the colored waters since wavelengths have been absorbed in a certain rates within water [28].

\subsection{Containers}

The solar disinfection process is carried out in transparent containers such as glass bottle, plastic bottle and bag which transmit sunlight [40]. Shape and color of the container may have significant impacts on the effectiveness of disinfection. Depending on the movement of the sun in the sky, the intensity of light that enters the bottle may change, and affects the efficiency of the disinfection. Thus, using round, conical bottles, not square or irregular shaped containers is suggested [28]. It is also noted that colorless containers allow the most transmittance of ultra-violet wavelengths in comparison to orange, yellow, red and green containers. The shallow water depth in the bag as opposed to the bottle, allows for better penetration of the wavelengths because the depth of water is less in bag than PET bottle [41, 42]. Plastic_bottles which are made of Poly Ethylene Terephthalate (PET) are considered the best choice since they do not have as much UV stabilizer as compared to PVC bottles, which are made of Poly Vinyl Chloride (PVC). Bottles that are scratched will not work as well as clear clean plastic. Glass bottles can be used for SODIS however they are not nearly as efficient as PET bottles. Window glass is not recommended as it does not transmit enough UV radiation into water. The increase in the amount of water in high volumes $(22 \mathrm{~L}-25 \mathrm{~L})$ can affect the disinfection efficiency, while the increase in the amount of water in the low volume water $(0.5-1.5 \mathrm{~L})$ does not cause any change in the disinfection efficiency [22, 43]. Further research is needed to detect effects of volume variations on solar disinfection.

\section{Inactivation of Microorganisms}

Numerous researches have been conducted to determine the effectiveness of the SODIS on microorganisms. It has been demonstrated that the lethal effect of sunlight is due to the strong synergistic effect of optical and thermal processes at temperatures exceeding $45^{\circ} \mathrm{C}$. Using solar radiation is effective disinfection method which is constantly being developed [24]. In addition to direct inactivation of solar radiation sunlight is absorbed by endogenous (e.g. cytochromes) and exogenous (e.g. humic substances) photosensitizers that produced highly reactive oxygen molecules such as hydrogen peroxide $\left(\mathrm{H}_{2} \mathrm{O}_{2}\right)$, singlet oxygen and superoxides which destroy bacteria [44-46].

Both gram positive and gram negative bacteria including Campylobacter jejuni, Enterococcus sp., Enteropathogenic E. coli, Mycobacterium avium, Mycobacterium intracellular, P. aeruginosa, Salmonella typhi, S. typhimurium, Shigella dysenteriae Type I, Shigella flexneri, Streptococcus faecalis, Staphylococcus epidermidis, Vibrio cholerae, Yersinia enterocolitica are inactivated at different levels by $6 \mathrm{~h}$ solar disinfection. However, $16 \mathrm{~h}$ of natural sunlight required for $1.3 \log$ reduction of Bacillus subtilis endospores $[10,15,28$, $39,47-50]$.

Solar disinfection is effective in inactivating some encysted parasitic Protozoa (Cryptosporidium, Giardia and Entamoeba) causing waterborne diseases. [14, 51, 52]. Most of these pathogenic protozoa can be destroyed in water samples that are continuously exposed to sunlight for 7 hours and kept at $50-60^{\circ} \mathrm{C}$ in 2 liter one side blackened bottles [52, 53]. Cryptosporidium parvum oocyst viability can be reduced by $86.3 \%$ and $97.7 \%$ during $8 \mathrm{~h}$ and $12 \mathrm{~h}$ strong solar exposure $[14,54]$. It should be noted that the cumulative dose as well as the way of dosing (continuously, intermittently, average radiation, as direct or diffuse UV) significantly affects the observed behavior of inactivation $[55,56]$. 
MS2, rotavirus, adenovirus, and poliovirus are effectively inactivated by UV-B $(\lambda=280-320 \mathrm{~nm})$ when water exposed to the full sunlight spectrum [57-60]. It leads modifications in the genome by producing photoproducts such as thymine dimers or bond breakage of the nucleic acid which will inhibit the reproduction of the viruses [61-62]. Both indirect endogenous and indirect exogenous effect of UV-A radiation is less efficient in inactivating viruses, because they rarely have such chromophores which act as sensitizers for the formation of reactive oxygen species (Calado 2013).

4 logs of MS2 was achieved in Swiss tap water in 6 hours at $22^{\circ} \mathrm{C}$ and a fluence rate of $1.34 \mathrm{~kJ} / \mathrm{cm} 2$ ) less than $1 \log$ of inactivation was obtained in Swiss tap water for phiX174 adenoviruses. High temperatures during SODIS enhanced inactivation efficacy, 6 logs in 6 hours could be expected at $45^{\circ} \mathrm{C}$ and with a fluence rate of $1.34 \mathrm{~kJ} / \mathrm{cm}^{2}[63]$.

It has been proven that solar disinfection is very effective in spores of phytopathogenic fungi, which are responsible for diseases of great incidence in agriculture and hospital distribution systems $[64,65]$. It is possible to inactivate about 1000 colonies per millilitre of spores of five types of the Fusarium species (F. equiseti, $F$. verticillioides, $F$. solani, $F$. oxysporum, and $F$. antophilum) with different level in bottle reactor during 1-6 h exposure to natural solar radiation in perfectly sunny day [66].

\section{Field Applications}

Solar disinfection is very well suited for rural communities of low income in developing countries, which do not have access to standard water purification systems, do not boil or chlorinate the water, and are only interested in treating the water required for their daily consumption. [67-68].

It is estimated that 5 million people treat their water by using SODIS method in homes, schools, health centers, and other institutions (depending on structural, political, and geographic circumstances) in 55 countries in Asia, Africa, and Latin America (Figure 2). According to statistics the risk of diarrhoea in the Tamil Nadu region of South East India was reduced by $40 \%$ by using solar disinfection [10].

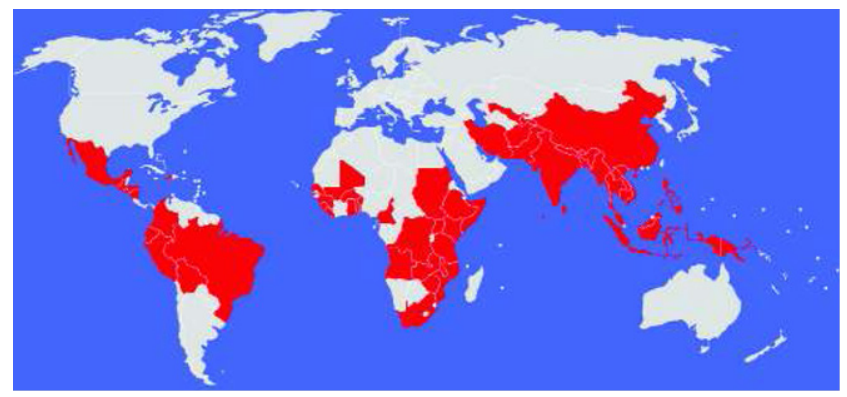

Figure 2. A map of the World indicating the 55 countries (Mc Guigan et al. [10]

The efficiency of solar disinfection for the inactivation of Total Coliforms (TC) and Escherichia coli (EC) in drinking water was tested with three types of bottles which were transparent, partially painted black (one half of the bottle, along the longitudinal axis), and totally black in rural communities of the Guachochi Municipality, in the Tarahumara Sierra, State of Chihuahua, Mexico. The results of study showed that the available water has to be disinfected before consumption. Furthermore, all microorganisms in this geographic region were completely inactivated by the use of solar radiation. Complete disinfection takes place by simply placing water bottles under the sunlight during whole day [67].

The results of experiment conducted by Narain et al. [69] in Roorkee which is located at 29.850 latitude and 77.880 longitudes at an elevation of $255 \mathrm{~m}$ above the sea level in India showed that there was a significant reduction in Total coliform (79.2\%), Turbidity (66.67\%), TDS (41.03\%) and EC (40.67\%) after exposing the sample for 8 hours (one day) on sunlight (Figure 3).

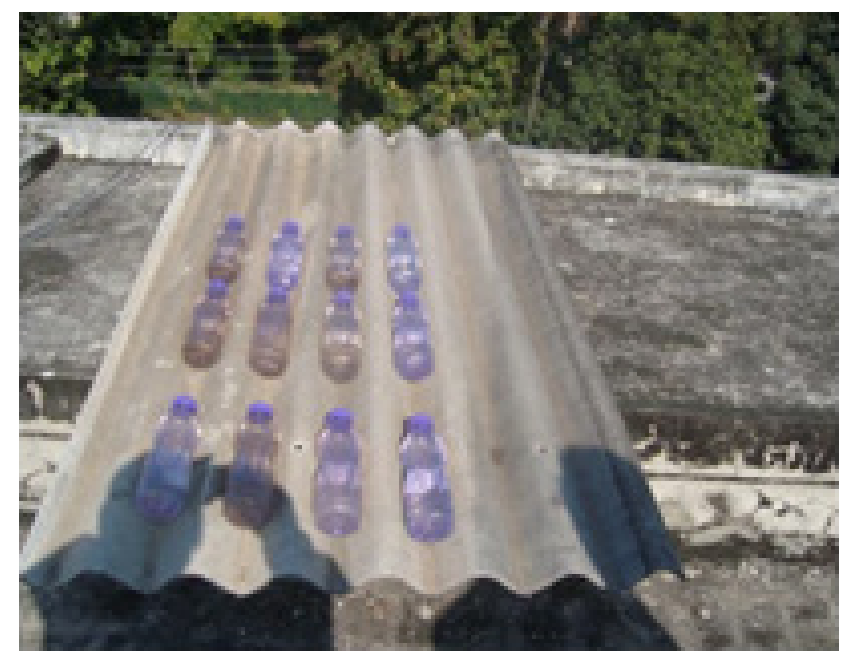

Figure 3. Solar disinfection application in India (Narain et. al. [69])

It was stated by Mahvi [70] approximately 3 logs reduction in fecal coliforms are possible by using bottles at the temperature of $39.6^{\circ} \mathrm{C}$. Replacing bottle with more transparent one, it would be possible to decrease the required contact time from $8 \mathrm{~h}$ to $6 \mathrm{~h}$ for $3 \operatorname{logs}$ reduction [70].

In studies conducted in Spain and Bolivia, the time required for complete inactivation of Campylobacter jejuni, Yersinia enterocolitica, enteropathogenic Escherichia coli, Staphylococcus epidermidis, and endospores of Bacillus subtilis was determined as follows: $C$. jejuni, $20 \mathrm{~min} ; S$. epidermidis, $45 \mathrm{~min}$; enteropathogenic E. coli, $90 \mathrm{~min}$; $Y$. enterocolitica, $150 \mathrm{~min}$. endospores of Bacillus subtilis approximately 2 days. SODIS was shown to be effective against the vegetative cells of a number of emerging waterborne pathogens; however, bacterial species which are spore forming may survive this intervention process under that conditions [40].

Samples of turbid water from open dug wells and clear water from shallow wells obtained on a weekly basis from Ndagwe sub-county in the central part of Uganda (latitude 
$0^{0} 20^{\prime} 15^{\prime \prime} \mathrm{N}$, longitude $32^{0} 33^{\prime} 51^{\prime \prime} \mathrm{E}$ and altitude $1,300 \mathrm{~m}$ ) were exposured to natural solar light in order to demonstrate that if glass bottles are as effective as PET bottles in terms of microbial inactivation. Results of this study showed that SODIS efficacy in glass bottle under tropical field conditions was comparable to PET plastic bottle [71]. This means users in these regions can choose containers depending on availability and preference of the user. The results of another study which conducted to assess the efficacy of the borosilicate glass tube reactor fitted with a compound parabolic collector (BGTR-CPC) over an extended period of 17 months under local weather conditions in Uganda which is a tropical country with two rainy and two dry seasons in the year showed that satisfactory bacterial inactivation (log reduction values $>6$ units or inactivation to below the limit of detection $<1$ $\mathrm{CFU} / 100 \mathrm{ml}$ ) was achieved during $6 \mathrm{~h}$ exposure [68].

In Kenya, water resource containing $10^{5}$ E.coli / $100 \mathrm{ml}$ of E.coli was effectively disinfected by using continuous flow reactor combined with CPC [72].

The SODIS method carried out under field conditions in the Tabernas Desert (Almeria, Southern Spain: latitude, $37^{0}$ $05^{\prime} 54$ ” N; longitude, $2^{\circ} 21^{\prime} 32$ ” W; altitude, $500 \mathrm{~m}$ ) with 1.5 L PET bottles containing turbid waters contaminated with C. parvum oocysts significantly reduced the potential viability of $C$. parvum oocysts. However, longer exposure times appear to be required than those required for the bacterial pathogens [73].

In another study, 8 areas in Bolivia were visited by researchers, and 644 families were interviewed on the basis of a structured questionnaire in order to predict current use of SODIS [74]. In the long run, it was concluded that bottles must be supplied regularly or adequately by an organization that will continue unlimited operations in the region concerned, or that a local plan must be initiated for the purchase of used PET bottles and transportation of the bottles to the cities.

The intention to use of SODIS in the future and actual use were investigated in two cities of Nicaragua by Alther et al. [75]. Families in La Paz Centro and Waslala were interviewed, half of which were using SODIS and half of which were not. According to the results of interview, the intention to use and actual use were mainly related to an overall positive attitude, intention to use was related to the use of SODIS by other people, and actual use is was related to knowledge about SODIS. In addition, SODIS users also stated that the frequency of diarrhea cases was significantly lower than SODIS nonusers. These results clearly indicate that increasing the number of promotional activities by selecting a promoter that can provide confidence as a new technology will increase the use of this method, and will decrease the rate of diarrhea.

Clinical field trials had been conducted to determine the efficiency of SODIS on reduction of diarrhea cases in Kenya [76, 77], India [78], Iran [70], and Cambodia [79].

It can be clearly seen from previous studies that widespread of SODIS usage appears to be one of the most effective solutions in preventing waterborne diseases in the area where safe water supply is limited.

\section{Limitations in Solar Disinfection}

The application of solar disinfection is very simple, but there are several limitations in solar disinfection. Since solar disinfection is a process based on sunlight, it is only suitable for areas that receive 300 days a year, and between latitudes $35^{\circ} \mathrm{N}$ and $35^{\circ} \mathrm{S}$ having the optimum exposure of sunlight $[28,33]$. The other limitation is lack of materials required for the process immediately. Clear, cylindrical bottles are most effective containers allowing solar radiation to obtain healthy drinking water. However, it may be difficult to supply large scale use in remote communities where plastic containers are not sold. In addition, such devices for enhancement (foil, solar panels, copper piping, and thermostat valves) were required for pasteurization of drinking water [36]. It is not possible to find these materials easily in less developed areas. On the other hand, the information about solar water heater is not common, so this method of water heating for large-scale usage is impractical in developing countries. In addition, the shelf-life of the disinfected water is very short. It should be consumed within 24 hours before reactivation of bacteria. Small-scale individual usage of plastic bottles for SODIS is a promising treatment method that can be implemented with minimal resources and little training. Based on these considerations, it can be concluded that the SODIS technique can only useful as a point-of-use intervention, rather than for large-scale water disinfection. Thus, there is a real need to develop simple and inexpensive alternatives to SODIS that are able to provide larger volumes of healthy clean drinking water $[80,81]$.

\section{Enhancement for Solar Disinfection of Water}

The efficiency of SODIS process is dependent on the solar irradiance which varies with the latitude, time of day, atmospheric conditions, and several environmental factors including initial water quality for example organic loading, turbidity, level, nature of the bacterial contamination. In addition, the resistance of microorganisms leads to variation in treatment times of solar disinfection [1]. These factors have led to the necessity of developing the solar disinfection method.

Because of strong synergy between optical and thermal inactivation at exceeding temperatures of $45^{\circ} \mathrm{C}$, many studies have been conducted to enhance the efficiency of solar disinfection. Periodic agitation, using foil to increase reflection rate, adding non-transmissive backing to the container, circulation of water on a black surface in a closed 
enclosure that passes UVA radiation, using a solar collector connected to a double glass enclosure, and painting the half of the bottle's black to increase the achievable temperatures are main examples of these enhancement applications $[22,35,39,67,71,82]$.

Other alternatives which are used to improve disinfection efficiency are design of SODIS bags where the solar dose per volume is increased, use of UVA dosimetric sensors (polyoxometalate, semiconductor photocatalyst and photodegradable dye) which indicate to the user when the desired dose has been received design of customised SODIS treatment systems which maximise the solar dose using compound parabolic collectors (CPC) and include UVA feedback sensors for automated control, and the use of semiconductor photocatalysis. By using reactors combined with CPC, $5 \log$ E.coli inactivation is obtained in open air, while non-CPC requires more than 1 hour contact time [83].

Photocatalytic materials such as $\mathrm{TiO}_{2}, \mathrm{ZnO}$ etc. are also used to increase the efficiency of solar disinfection. During photocatalytic disinfection the hydroxyl radical suggested to be the primary species that is responsible for microorganism inactivation. Other reactive species (ROS) such as $\mathrm{H}_{2} \mathrm{O}_{2}, \mathrm{O}^{--}{ }_{2}$ can cause fatal damage to microorganisms by disruption of the cell membrane or by attacking DNA and RNA. Other effects of photocatalysts include damage to the respiratory system within the cells and loss of fluidity and increase ion permeability in the cell membrane [55, 84-86].

The exposure time required to achieve desired reductions is shorten by using solar photocatalytic materials with containers. The PET bottles with solar photocatalytic (SPC) inserts reduces the exposure time by approximately $25 \%$ compared to standard PET bottles, while solar photocatalytic (SPC) coated glass bottle reduces approximately $80 \%$ to achieve inactivation compared to the uncoated bottle [1] Using borosilicate glass bottles $20 \%$ effective than PET bottles because of their good solar light transmittance. Similarly, using smaller volume bottles exhibited superior performance to larger volume bottles [10]. Glass rings, glass rods and porcelain beads with P25 powder also has been shown as an effective application on disinfection [87].

It is understood from results of previous studies, these methods help to improve or enhance the traditional solar disinfection process $[22,35,39,67,82]$ since over $6 \log$ E.coli inactivation can be achieved by using these ways $[39,71]$.

\section{Conclusion and Suggestions}

Water and energy consumption has increased much faster and disproportionately than the human population in recent years, which causes the degradation of the environment and natural sources. Difficulty in access to safe drinking water and water stress in the ecosystem presents danger in many parts of the world. The need to access safe drinking water from poor quality water sources leads people to find low cost and sustainable methods. It is important that the method to be used is sustainable and environmentally friendly. It is not possible to use the latest new technologies all over the world. While suggesting technologies, it is necessary to pay attention to many issues such as regional leads, economic conditions, water characteristics, natural resources, location characteristics and experiences. Solar energy, which has the highest potential and sustainability among all renewable energy sources, can be used in particular areas. It has been proven that sunlight is effective in the inactivation of pathogenic microorganism strains that are responsible for almost all waterborne diseases. Different raw water sources contain natural organic matter in different amounts depending on the surrounding basin and geological conditions. The presence of natural organic substances can negatively affect pathogen inactivation by sunlight. In addition, some pathogenic microorganisms may resist inactivation by sunlight. Semiconductor photocatalytic methods used with solar energy can be used as a good alternative to pathogen removal as well as mineralization of natural organic materials to prevent all these negative effects. Water treatment and efficient inactivation can be obtained by effective design of solar energy collection technology.

\section{REFERENCES}

[1] J. A. Byrne, P. A. Fernandez-Ibañez, P. S. M. Dunlop, D. M.A. Alrousan, and J.W.J. Hamilton. Photocatalytic Enhancement for Solar Disinfection of Water: A Review, International Journal of Photoenergy, Vol.2011, 1-12, 2011.

[2] J. Blanco, S. Malato, P. Fernández-Ibañez, D. Alarcón, W. Gernjak, and M.I. Maldonado. Review of feasible solar energy applications to water processes, Renewable and Sustainable Energy Reviews, Vol.13, 1437-1445, 2009.

[3] P. Kalt, C. Birzer, H. Evans, A. Liew, M. Padovan, and M. Watchman. A Solar Disinfection Water Treatment System for Remote Communities, Procedia Engineering, Vol.78, 250 $258,2014$.

[4] A. Ahsan, M. Imteaz, U.A. Thomas, M. Azmi, A. Rahman, and N.N. Nik Daud. Parameters affecting the performance of a low cost solar still, Applied Energy, Vol.114, 924-930, 2014.

[5] S. Bofill-Mas, M. Rusiñol, X. Fernandez-Cassi, A. Carratalà, A. Hundesa, and R. Girones. Quantification of Human and Animal Viruses to Differentiate the Origin of the Fecal Contamination Present in Environmental Samples, BioMed Research International, Vol.2013, 1-11, 2013.

[6] G.W. McKinney, D. J. Lawrence, T. H. Prettyman, R. C. Elphic, W. C. Feldman, and J. J. Hagerty. CNPX benchmark for cosmic ray interactions with the Moon, J. Geophys. Res., Vol.111, 1-14, 2006.

[7] H.L.G. Waarbeek, N.H.T.M. Dukers-Muijrers, H. Vennema, C.J.P.A Hoebe. Waterborne Gastroenteritis Outbreak At A Scouting Camp Caused By Two Norovirus Genogroups: G1 And G11., J. Clin. Virol. Vol.47, No.3, 268-272, 2010. 
[8] M. Riera-Montes, K. Brus Sjölander, G. Allestam, E. Hallin, K.O., Hedlund, and M. Löfdahl. Waterborne norovirus outbreak in a municipal drinking-water supply in Sweden, Epidemiology and Infection, Vol.139, No.12, 1928-1935, 2011.

[9] N.P. Nenonen, C. Hannoun, C.U. Larsson, and T. Bergström. Marked genomic diversity of norovirus genogroup I strains in a waterborne outbreak, Applied and Environmental Microbiology, Vol.78, No.6, 1846-1852, 2012.

[10] K.G. McGuigan, R.M. Conroy, H.J. Mosler, M.du Preez, E. Ubomba-Jaswa, and P. Fernandez-Ibanez. Solar water disinfection (SODIS): a review from bench-top to roof-top, J Hazard Mater., Vol. 235-236, 29-46, 2012.

[11] M.I. Polo-Lopez, G.-F.I. Oller and P. Fernández-Ibáñez. Solar disinfection of fungal spores in water aided by low concentrations of hydrogen peroxide, Photochemical \& Photobiological Sciences, Vol. 10, 381-388, 2011.

[12] W. Heaselgrave, S. Kilvington. The efficacy of simulated solar disinfection (SODIS) against Ascaris, Giardia, Acanthamoeba, Naegleria, Entamoeba and Cryptosporidium, Acta Trop, Vol.119, 138-143, 2011.

[13] L.F. Caslake, D.J Connolly, V. Menon , C.M. Duncanson , R.Rojas, J. Tavakoli. Disinfection of contaminated water by using solar irradiation, Appl Environ Microbiol., Vol.70, No.2, 1145-1150, 2004.

[14] K.G. McGuigan, F. Mendez-Hermida, J.A. Castro-Hermida, E. Ares-Mazas, S.C. Kehoe, M. Boyle, C. Sichel, P. Fernandez-Ibanez, B.P. Meyer, S. Ramalingham, and E.A. Meyer. Batch solar disinfection inactivates oocysts of Cryptosporidium parvum and cysts of Giardia muris in drinking water, J. Appl. Microbiol., Vol.101, 453-463, 2006.

[15] M. Wegelin, S. Canonica, K. Mechsner, F. Pesaro, and A. Metzler. Solar water disinfection: scope of the process and analysis of radiation experiments, J. Water SRT-Aqua, Vol.43, 154-169, 1994.

[16] R.M. Conroy, M. Elmore-Meegan, T. Joyce, K.G. McGuigan, J. Barnes. Solar disinfection of drinking water and diarrhoea in Maasai children: a controlled field trial, Lancet, Vol.348, No.9043, 1695-1697, 1996.

[17] L.R. Wilson, B.C. Rowan, N. Robertson, O. Moudam, A.C. Jones, B.S. Richards. Characterization and reduction of reabsorption losses in luminescent solar concentrators, Appl Opt., Vol.49, No.9, 1651-1661, 2010.

[18] S. Malato, P. Fernández-Ibáñez, M.I. Maldonado, J. Blanco, W. Gernjak. Decontamination and disinfection of water by solar photocatalysis: recent overview and trends, Catal. Today, Vol.147, 1-59, 2009.

[19] A.B. Pandit and J.K. Kumar, Drinking Water Disinfection Techniques, Taylor \& Francis Group, New York, 2012

[20] M.J. Mattle, D. Vione, and T. Kohn. Conceptual Model and Experimental Framework to Determine the Contributions of Direct and Indirect Photoreactions to the Solar Disinfection of MS2, phiX174, and Adenovirus, Environ Sci Technol., Vol.49, No.1, 334-342, 2015.

[21] F. Joux, W.H. Jeffrey, Lebaron P, Mitchell DL. Marine bacterial isolates display diverse responses to UV-B radiation, Appl Environ Microbiol., Vol.65, No.9, 3820-3827, 1999.
[22] S.C. Kehoe, T.M. Joyce, P. Ibrahim, J.B. Gillespie, R.A. Shahar and K.G. McGuigan. Effect of agitation, turbidity, aluminium foil reflectors and container volume on the inactivation efficiency of batch-process solar disinfectors, Water Res., Vol.35, 1061-1065, 2001.

[23] K.G. McGuigan, T.M. Joyce and R.M. Conroy J. Solar disinfection: use of sunlight to decontaminate drinking water in developing countries, Med. Microbiol., Vol. 48, 785-787, 1999.

[24] K.G. McGuigan, T.M. Joyce, R.M. Conroy, J.B. Gillespie, M. Elmore-Meegan. Solar disinfection of drinking water contained in transparent plastic bottles: characterizing the bacterial inactivation process, J. Appl. Microbiol., Vol.84, 1138-1148, 1998.

[25] S. Dejung, I. Fuentes, G. Almanza, R. Jarro, L. Navarro, G. Arias, E. Urquieta, A. Torrico, W. Fenandez, M. Iriarte, C. Birrer, W.A. Stahel, and M. Wegelin. Effect of Solar water disinfection (SODIS) on model microorganisms under improved and field SODIS conditions, Journal of Water Supply: Research and Technology-AQUA, Vol.56, No.4, 245-256, 2007.

[26] M. Berney, H.U. Weilenmann and T. Egli. Adaptation to UVA radiation of $\mathrm{E}$. coli growing in continuous culture, $\mathrm{J}$ Photochem Photobiol B, Vol.86, 149-159, 2007.

[27] P.M. Oates, P.S. Martin, F. Polz. Solar disinfection (SODIS): simulation of solar radiation for global assessment and application for point-of-use water treatment in Haiti, Water Res, Vol.37, 47-54, 2003.

[28] A.R. Acra, Z. Raffoul and Y. Karahagopian. Solar disinfection of drinking water andal rehydration solutions: guidelines for household application in developing countries, UNICEF, SODISWATER Project, American University of Beirut, 1984.

[29] Y. Mamane, E. Petroulakis, Y. Martineau, T.A. Sato, O. Larsson, V.K. Rajasekhar, N. Sonenberg, E. Petroulakis., Y. Martineau, T.A. Sato, O. Larsson, V.K. Rajasekhar, N. Sonenberg, Y. Martineau, T.A. Sato, O. Larsson, V.K. Rajasekhar, N. Sonenberg, T.A. Sato., O. Larsson, V.K. Rajasekhar, N. Sonenberg, O. Larsson, V.K. Rajasekhar, N. Sonenberg, V.K. Rajasekhar, N. Sonenberg. Epigenetic activation of a subset of mRNAs by eIF4E explains its effects on cell proliferation, PLoS ONE, Vol.2, No.2, 1-13, 2007.

[30] A.I. Silverman, B.M. Peterson, A.B. Boehm, K. McNeill, and K.L. Nelson. Sunlight Inactivation of Human Viruses and Bacteriophages in Coastal Waters Containing Natural Photosensitizers, Environ. Sci. Technol., Vol.47, No.4, 18701878, 2013.

[31] S. Giannakis, M.I.P. Lopez, D. Spuhler, J.A.S. Perez, P. Fernández-Ibáñez, and C. Pulgarin. Solar disinfection is an augmentable, in situ-generated photo-Fenton reaction-part 1: a review of themechanisms and the fundamental aspects of the process, Appl Catal B Environ, Vol.199, 199-223, 2016.

[32] M.A. Alotaibi, W. Heaselgrave. Solar Disinfection of Water for Inactivation of Enteric Viruses and its Enhancement by Riboflavin. Food Environ Virol., Vol.3, 70-73, 2011.

[33] T.C. Kandpal, S.S. Matthur, Physics of solar water disinfection: an introductory review, Solar Water Disinfection, Proceedings of a Workshop Held at the Brace Research Institute, Montreal, Que., Canada, 133-154, 1990. 
[34] J. Burch, K.E. Thomas. An overview of water disinfection in developing countries and the potential for solar thermal water pasteurization. Technical Report (National Renewable Energy Laboratory, Golden, Colo), 1998.

[35] T.S. Saitoh and H.H. ElGhetany. A pilot solar water disinfecting system: performance analysis and testing, Sol. Energy, Vol.72, 261-269, 2002.

[36] A.J.F. Jørgensen, K. Nøhr, H. Sørensen and F. Boisen. Decontamination of drinking water by direct heating in solar panels, J. Appl. Microbiol., Vol.85, 441-447, 1998.

[37] Rijal, G. K. \& Fujioka, R. S. Synergistic effect of solar radiation and solar heating to disinfect drinking water sources. Water Sci. Technol. 43(12), 155-162, 2001.

[38] H. Gómez-Cousoa, M. Fontán-Sainz, P. Fernández-Ibánez, E. Ares-Mazás. Speeding up the solar water disinfection process (SODIS) against Cryptosporidium parvum by using $2.51 \mathrm{static}$ solar reactors fitted with compound parabolic concentrators (CPCs), Acta Tropica, Vol.124, 235-242, 2012.

[39] B. Sommer, A. Mariño, Y. Solarte, M.L. Salas, C. Dierolf, C. Valiente, D. Mora, R. Rechsteiner, P. Setter, W. Wirojanagud, H. Ajarmeh, A. AlHassan, M. Wegelin. SODIS-an emerging water treatment process, J. Water SRT - Aqua, Vol.46, 127-137, 1997.

[40] M. Boyle, C. Sichel, P. Fernández-Ibáñez, G.B. Arias-Quiroz, M. Iriarte-Puna, A. Mercado, E. Ubomba-Jaswa and K. G. McGuigan. Bactericidal effect of solar water disinfection under real sunlight conditions, Appl Environ Microbiol, Vol.74, 2997-3001, 2008.

[41] M. M. Foran. An analysis of the time to disinfection and the source water and environmental challenges to implementing a solar disinfection technology (SolAgua), MSc Thesis, Boston, Massachusetts, 2007.

[42] A. Dessie, E. Alemayehu, S. Mekonen, W. Legesse, H. Kloos and A. Ambelu. Solar disinfection: an approach for low-cost household water treatment technology in Southwestern Ethiopia, J Environ Health Sci Eng., Vol.12, No.1, 12-25, 2014

[43] R.H. Reed, S.K. Mani and V. Meyer. Solar photo-oxidative disinfection of drinking water: preliminary field observations, Letters in Applied Microbiology, Vol.30, 432-436, 2000.

[44] G. Whitelam and G. Codd. Damage to microorganisms by light, Special Publications of the Society for General Microbiology, Vol.17, 129-169, 1986.

[45] S. Farr and T. Kogoma. Oxidative stress responses in Escherichia coli and Salmonella typhimurium, Microbiological Reviews, Vol.55, 561-585, 1991.

[46] S.C. Kehoe, M.R. Barer, L.O. Devlin and K.G. McGuigan. Batch process solar disinfection is an efficient means of disinfecting drinking water contaminated with Shigella dysenteriae type, Letters in Applied Microbiology, Vol.38, 410-414, 2004.

[47] R.J. Smith, S.C. Kehoe, K.G. McGuigan, M.R. Barer. Effect of simulated solar disinfection of water on infectivity of Salmonella typhimurium, Lett Appl Microbiol, Vol.31, 284-288, 2000.

[48] J. Lonnen, S. Kilvington, S.C. Kehoe, F. Al-Touati and K.G. McGuigan. Solar and photocatalytic disinfection of protozoan, fungal and bacterial microbes in drinking water, Water Res, Vol. 39, 877-883, 2005.

[49] M. Berney, H.U. Weilenmann, A. Simonetti and T. Egli. Efficacy of solar disinfection of Escherichia coli, Shigella flexneri, Salmonella Typhimurium and Vibrio cholerae, J Appl Microbiol, Vol.101, 828-836, 2006.

[50] W. Heaselgrave and S. Kilvington. Antimicrobial Activity of Simulated Solar Disinfection against Bacterial, Fungal, and Protozoan Pathogens and Its Enhancement by Riboflavin, Applied and Environmental Microbiology, Vol. 76, No. 17, 6010-6012, 2010.

[51] F. Mendez-Hermida, J.A. Castro-Hermida, E. Ares-Mazas, S.C. Kehoe and K.G. McGuigan. Effect of batch-process solar disinfection on survival of Cryptosporidium parvum oocysts in drinking water, Appl Environ Microbiol, Vol.71, 1653-1654, 2005.

[52] A.H. Mohamed, M. Galal, G.Y. Osman, M. Aboamer. Influence of Solar Energy on Encysted Parasitic Protozoa Giardia and Entamoeba spp in Water-Treatment Plants, Egypt. Journal of Materials Science and Engineering B, Vol.4, No.10, 284-292, 2014.

[53] S. Mtapuri-Zinyowera, N. Midzi, C. E. Muchaneta-Kubara, T. Simbini and T. Mduluza. Impact of solar radiation in disinfecting drinking water contaminated with Giardia duodenalis and Entamoeba histolytica/dispar at a point-of-use water treatment, J Appl Microbiol, Vol.106, 847-852, 2009.

[54] F. Mendez-Hermida, E. Ares-Mazas, K.G. McGuigan, M. Boyle, C. Sichel,and P. Fernández-Ibáñez. Disinfection of drinking water contaminated with Cryptosporidium parvum oocysts under natural sunlight and using the photocatalyst $\mathrm{TiO}_{2}$, J Photochem Photobiol B, Vol.88, 105-111, 2007.

[55] A.G. Rincón and C. Pulgarin. Field solar E. coli inactivation in the absence and presence of $\mathrm{TiO} 2$ : is UV solar dose an appropriate parameter for standardization of water solar disinfection?, Solar Energy, Vol.77, 635-648, 2004.

[56] H. Merwald, G. Klosner, C. Kokesch, M. Der-Petrossian, H. Honigsmann and F. Trautinger. UVA-induced oxidative damage and cytotoxicity depend on the mode of exposure, $\mathrm{J}$ Photochem Photobiol B, Vol.79, 197-207, 2005.

[57] T. Kohn and K.L. Nelson. Sunlight-Mediated Inactivation of MS2 Coliphage via Exogenous Singlet Oxygen Produced by Sensitizers in Natural Waters, Environ. Sci.Technol., Vol. 41, No.1, 192-197, 2007.

[58] D.C. Love, A. Silverman and K. L. Nelson. Human Virus and Bacteriophage Inactivation in Clear Water by Simulated Sunlight Compared to Bacteriophage Inactivation at a Southern California Beach, Environ. Sci. Technol., Vol.44, 6965-6970, 2010.

[59] O.C. Romero, A.P. Straub, T. Kohn, and T. H. Nguyen. Role of temperature and Suwannee River natural organic matter on inactivation kinetics of rotavirus and bacteriophage MS2 by solar irradiation, Environ Sci Technol., Vol.45, 10385-10393, 2011.

[60] M.B. Fisher, M. Iriarte, and K.L. Nelson. Solar water disinfection (SODIS) of Escherichia coli, Enterococcus spp. and MS2 coliphage: effects of additives and alternative container materials, Water Res., Vol.46, 1745-1754, 2012.

[61] B.M. Pecson, L.V. Martin, and T. Kohn. Quantitative PCR 
for determining the infectivity of bacteriophage MS2 upon inactivation by heat, UV-B radiation, and singlet oxygen: advantages and limitations of an enzymatic treatment to reduce false-positive results, Appl Environ Microbiol., Vol.75, 5544-5554, 2009.

[62] A.D. Calado. Solar disinfection of viruses (SODIS): inactivation of coliphages MS2 and phiX174, human adenovirus and echovirus in water from Switzerland and India, Master Thesis, 2013.

[63] A. Carratalà, A.D. Calado, M.J. Mattle, R. Meierhofer, S. Luzi and T. Kohn. Solar Disinfection of Viruses in Polyethylene Terephthalate Bottles, Appl. Environ. Microbiol., Vol.82, No.1, 279-288, 2016.

[64] P.E. Nelson, M.C. Dignani, and E.J. Anaissie. Taxonomy, Biology, and Clinical Aspects of Fusarium Species, Clinical Microbiology Reviews, Vol.7, No.4, 479-504, 1994.

[65] C. Sichel, P. Fernández-Ibáñez, M. de Cara, and J. Tello. Lethal synergy of solar UV-radiation and $\mathrm{H}_{2} \mathrm{O}_{2}$ on wild Fusarium solani spores in distilled and natural well water, Water Res, Vol.43, 1841-1850, 2009.

[66] C. Sichel, M. de Cara, J. Tello, J. Blanco, and P. Fernández-Ibáñez. Solar photocatalytic disinfection of agricultural pathogenic fungi: Fusarium species, Applied Catalysis B: Environmental, Vol.74, 152-160, 2007.

[67] A. Martín-Domínguez, M.T. Alarcón-Herrera, I.R. Martín-Domínguez, and A. González-Herrera. Efficiency in the disinfection of water for human consumption in rural communities using solar radiation, Solar Energy, Vol.78, 31-40, 2005.

[68] R. Nalwanga, B. Quilty, C. Muyanja, P. Fernández-Ibáñez, and K.G. McGuigan. Evaluation of solar disinfection of E. coli under Sub-Saharan field conditions using a $25 \mathrm{~L}$ borosilicate glass batch reactor fitted with a compound parabolic collector, Solar Energy, Vol.100, 195-202, 2014.

[69] S. Narain, A.K. Abebe, U.C. Chaube, and S.K. Mishra. Feasibility of solar energy in disinfection of water source for an Indian village -A case study, International Journal of Environmental Sciences, Vol.2, No.4, 2338-2345, 2012.

[70] A.H. Mahvi. Feasibility of Solar Energy in Disinfection of Drinking Water in Iran, American-Eurasian J. Agric. \& Environ. Sci, Vol.2, 407-410, 2007.

[71] J.K. Asiimwe, B. Quilty, C.K. Muyanja, and K.G. McGuigan. Field comparison of solar water disinfection (SODIS) efficacy between glass and polyethylene terephalate (PET) plastic bottles under sub-Saharan weather conditions, J Water Health, Vol.11, 729-737, 2013.

[72] L.W. Gill, C. Price. Preliminary observations of a continuous flow solar disinfection system for a rural community in Kenya, Energy, Vol.35, 4607-4611, 2010.

[73] H. Gómez-Couso, M. Fontán-Saínz, C. Sichel, P. Fernández-Ibáñez, and E. Ares-Mazás. Efficacy of the solar water disinfection method in turbid waters experimentally contaminated with Cryptosporidium parvum oocysts under real field conditions, Tropical Medicine and International Health, Vol.14, No.6, 620-627, 2009.

[74] S. Heri, H.J. Mosler. Factors Affecting the Diffusion of Solar Water Disinfection: A Field Study in Bolivia, Health Education \& Behavior, Vol.35, No.4, 541-560, 2008.
[75] A.M. Altherr, H.J. Mosler, R. Tobias, F. Butera. Attitudinal and Relational Factors Predicting the Use of Solar Water Disinfection: A Field Study in Nicaragua, Health Education \& Behavior, Vol.35, No.2, 207-220, 2008.

[76] R.M. Conroy, M.E. Meegan, T. Joyce, K.G. McGuigan, J. Barnes. Solar disinfection of drinking water protects against cholera in children under 6 years of age, Archives of Disease in Childhood, Vol.85, No.4, 293-295, 2001.

[77] M. du Preez, R.M. Conroy, S. Ligondo, J. Hennessy, M. Elmore-Meegan, A. Soita, and K.G. McGuigan, Randomized Intervention Study of Solar Disinfection of Drinking Water in the Prevention of Dysentery in Kenyan Children Aged under 5 Years, Environ. Sci. Technol., Vol.45, 9315-9323, 2011.

[78] A. Rose, S. Roy, V. Abraham, G. Holmgren, K. George, V. Balraj, S. Abraham, J. Muliyil, A. Joseph, G. Kang. Solar disinfection of water for diarrhoeal prevention in southern India. Archives of Disease in Childhood, Vol.91, No.2, 139141,2006

[79] K.G. McGuigan, P. Samaiyar, M. du Preez, and R.M. Conroy. High Compliance Randomized Controlled Field Trial of Solar Disinfection of Drinking Water and Its Impact on Childhood Diarrhea in Rural Cambodia, Environ. Sci. Technol., Vol.45, 7862-7867, 2011.

[80] C. Rojko. Solar Disinfection of Drinking Water, A Thesis of Master of Science, Worcester Polytechnic Institute, 2003.

[81] N.M. Makwana, R. Hazael, P.F. McMillan, and J.A. Darr. Photocatalytic water disinfection by simple and low-cost monolithic and heterojunction ceramic wafers, Photochem. Photobiol. Sci., Vol.14, 1190-1196, 2015.

[82] G.K. Rijal and R.S. Fujioka. Use of reflectors to enhance the synergistic effects of solar heating and solar wavelengths to disinfect drinking water sources, Water Sci. Technol., Vol.48, 481-488, 2003.

[83] E. Ubomba-Jaswa, C. Navntoft, M.I. Polo-López, P. Fernández-Ibáñez and K.G. McGuigan. Solar disinfection of drinking water (SODIS): an investigation of the effect of UV-A dose on inactivation efficiency, Photochem. Photobiol. Sci., Vol.8, 587-595, 2009.

[84] M.I. Litter. Heterogeneous photocatalysis: transition metal ions in photocatalytic systems, Applied Catalysis B, Vol.23, No.2-3, 89-114, 1999.

[85] A.G. Rincón, C. Pulgarin, N. Adler, and P. Peringer. Interaction between E. coli inactivation and DBP-precursors - dihydroxybenzene isomers - in the photocatalytic process of drinking-water disinfection with $\mathrm{TiO}_{2}$, Journal of Photochemistry and Photobiology A, Vol.139, No. 2-3, 233-241, 2001.

[86] K. Lawrie, A. Mills, M. Figueredo-Fernandez, S. Gutierrez-Alfaro, M. Manzano, M. Saladin. UV dosimetry for solar water disinfection (SODIS) carried out in different plastic bottles and bags, Sensors and Actuators B: Chemical, Vol.208, 608-615, 2015.

[87] J.M. Meichtry, H.J. Lin, I.K. Levy, E.A. Gautier, M.A. Blesa, and M.I. Litter. Low-cost $\mathrm{TiO}_{2}$ photocatalytic technology for water potabilization in plastic bottles for isolated regions. Photocatalyst fixation. Journal of Solar Energy Engineering, Vol. 129, 119-126, 2007. 